\title{
GENETIC PRINCIPLES RELATING TO IMPROVEMENT OF MILK YIELD IN SHEEP AND GOATS ${ }^{1}$
}

\author{
M. P. Petrović, C. Mekić, Dragana Ružić, M. Žujović
}

Content: In this review paper major genetic principles relating to improvement of milk yield in sheep and goats are discussed and trends existing in breeding programmes in certain European countries analyzed. Genetic principles relating to improvement of milk yield are emphasized but also intensive development of new methods in genetics aiming to explain the issue of improvement of milk production from other aspects. In order to determine genetic parameters for somatic cell count, mathematical approach has been defined for calculation of lactation average in relation to somatic cell count in milk from sheep and goats. Using genetic knowledge and good breeding programmes it is possible to achieve, with more or less success, annual genetic progress of milk traits. Variations in evaluated annual genetic increase of milk yield in sheep are from $0,8-6,1$ $\mathrm{kg}$, and in goats from $0,59-13,65 \mathrm{~kg}$, which means that their milk yield during single year could be improved by $1-2 \%$.

Key words: sheep, goat, genetic parameters, milk yield, breeding programme

\section{Introduction}

Production of sheep and goat milk is mainly based on use of local populations in different production systems (Boyazoglu and Flamant, 1990; Petrović et al., 2001, 2003; Žujović et al., 2002; Ugarte, 2003).

Improvement of milk yield in sheep and goats relates not only to quantity and chemical composition of milk but also to somatic cell count in milk which beside the effect on technology, quantity and quality of cheeses represents important selection criterion for improvement of animal resistance to mastitis (Barillet et al., 2004).

Majority of local sheep and goat populations which posses solid genetic potential in regard to milk yield but, in order to realize such potential, it is necessary to carry out systematically and programmed improvement/breeding (Petrović, 2000). In this sense, selection as continuing process represents good way for realization of genetic progress (Petrović et al., 2003; 2004).

Selection programmes today are based on numerous breeding factors which are included in analysis, all data relating to milk traits are considered to be important (Petrović et al., 2001; 2002). Efficient work on genetic improvement of milk yield in sheep and goats demands knowledge of hereditary and factors of the environment (Boylan, 1989, Marie et al., 1996; Petrović et al., 2000; Barillet et al., 2004) but also good models for estimation of breeding value (Ugarte, 1996, 2003; Serrano et al., 1997).

Objective of this review paper was to discuss more important genetic possibilities for improvement of milk yield in sheep and goats and demonstrate new trends in breeding programmes in certain European countries.

\section{Increase of quantity and quality of milk}

When discussing milk yield in sheep and goats, typical production traits include quantity of milk, content of milk fat and milk protein. Fat and protein are often expressed in quantity, although it is not always necessary.

Genetic parameters of milk traits in sheep and goats are research topic of numerous researchers (Carriedo et al., 1995; Analla et al., 1996; Barillet, 1997; Sanna et al., 1997; Petrović et al., 2000; 2001; Serrano et al., 2001; Serradilla, 2002; Petrović et al., 2005), and obtained results are applied in practice in selection although there are certain deviations/exceptions. In the following table some of genetic parameters of major milk traits in sheep and goats are stated.

1 Review paper supported by the Ministry of Science and Environment Protection, Project no. TR6858 - Revijalni rad je finansiran od strane Ministarstva za nauku i zaštitu životne sredine Projektom broj: TR6858

2 Dr Milan P. Petović, scientific counselor, mr Dragana Ružić-Muslić, research assistant, dr Miroslav Žujović, scientific counselor, Institute for Animal Husbandry, Belgrade-Zemun, dr Cvijan Mekić associate professor, Faculty of Agriculture, Belgrade 
Table 1. Heritability and genetic correlations of milk yield traits in sheep and goat (Serradilla, 2002; Petrović at al., 2005)

\begin{tabular}{|l|l|c|c|c|}
\hline \multicolumn{2}{|c|}{ Trait } & \multirow{2}{*}{ Heritability } & \multicolumn{2}{c|}{ Genetic correlations } \\
\cline { 4 - 5 } & Sheep & 0,38 & Milk yield & Fat content \\
\hline \multirow{2}{*}{ Milk yield } & Goat & 0,35 & - & - \\
\hline \multirow{2}{*}{ Fat content } & Sheep & 0,48 & $-0,31$ & - \\
\cline { 2 - 5 } & Goat & 0,47 & $-0,38$ & - \\
\hline \multirow{2}{*}{ Protein content } & Sheep & 0,51 & $-0,47$ & 0,78 \\
\cline { 2 - 5 } & Goat & 0,50 & $-0,47$ & 0,62 \\
\hline
\end{tabular}

Based on data presented in table as well as data from research literature stated in this paper it can be concluded that heritability for milk quantity in sheep and goats varies in interval from $0,30-0,40$ and that content of fat and protein with values in interval from $0,45-0,55$, even to 0,60 , as stated by Barillet et al., 2004. However, correlation between quantity of milk and fat content varies from 0,30 to 0,40 , whereas correlation between milk yield and protein content is higher and varies from 0,40 to 0,50 .

Considering the actual situation of negative correlation between milk quantity and fat and protein content it can be concluded that compromise in selection is inevitable. Compromise as global objective in regard to simultaneous improvement of quantity and composition of milk according to Barillet (1997) reflects in substitution of quantity of milk with linear combination of quantity of fat and protein and potential combination of these two traits with content of fat and protein.

Intensive development of new methods in the field of genetics has made it possible to discuss and explain the problem of improvement of milk yield in sheep and goats from other aspects (Petrović, 2000).

Milk traits in goats were topics in numerous researches, so knowledge on the effect of major genes on protein content and especially on level of casein as main protein fraction in milk is important. However, not entire casein haplotype is reviewed but more attention is directed to $\alpha \mathrm{s} 1$ as most variable goat milk casein with several alleles.

Not so long ago, Grosclaude et al. (1997) have discovered 7 variants of as1-casein in several goat breeds and classified them according to the degree of casein synthesis to:
A, B,C- strong
E- intermedial
F, G- weak
O- zero

Such research, together with development of PCR technique have contributed to successful application of acquired knowledge in selection, such is the case of Alpine goat breed and Saanen goat breed in France, not only in test stations but also on farms.

It was determined that milk from certain goat genotypes contains more protein and fat (Mahe et al.,1993; Barbieri et al., 1995; Manfredi et al., 1995). It was also established that cheese produced from milk originating from certain goat genotypes has better sensor traits (Delacroix-Buchet and Lambaret, 2000).

In sheep, genetic polymorphism of milk proteins was established and $\alpha$ s 1 -casein and $\beta$-lacto globulin separated. In year 1967, King (1967) detected 2 variants of as1-caseina („normal” and „Wales“ variant) and Chianese et al. (1996) described 5 variants (A, B, C, D, E). However, only „Wales” or variant D how it is called today had greater application in selection of sheep (Pirisi et al., 1999).

Polymorphism of $\beta$-lacto globulin didn't find expected practical application in selection of sheep on milk yield in spite of the fact that correlation between variants A and B and some technological characteristics of milk was established (Recio et al., 1997; Gutierrez-Gil et al., 2001). Maybe future research will come up with explanations of this problem.

\section{Increase of resistance to mastitis}

Mastitis in sheep and goats is considered to be one of the most important health problems. Economical losses due to mastitis are huge. Each single animal with this problem is producing by 10 do $15 \%$ less milk and many high quality animals were excluded from breeding early because of this problem.

Western authors have determined that infected udder gives by $20 \%$ less milk than healthy ones and in case of repeated infection even up to $30 \%$ less milk. Losses include also cost of medical treatment of 
diseased livestock, elimination of heads of livestock that can not be treated/cured and bad quality of milk for processing (Gonzales-Rodrigues et al., 1995; Bergonnier et al., 1995).

Somatic cell count (SCC) with presence of pathogenic micro organisms is reliable sign of mastitis.

For longer period of time, experts engaged in selection have been working on determination of genetic parameters for somatic cell count. Mathematical approach has been defined for that purpose which was based on normal distribution for calculation of lactation average of somatic cell count in milk from sheep and goats (LSCS).

Research showed that heritability for LSCS in goats was 0,19 and as stated by Rupp et al. (2004) it was higher compared to sheep, whereas genetic correlations of LSCS with milk traits demonstrated values close to zero.

Considering the importance of this problem new research is necessary in sheep and goats in order to find biological correlation of somatic cells and intramammary gland infection.

\section{Increase of efficiency of breeding programmes}

In general speaking, organization of breeding programmes in production of sheep and goat milk is based on following elements:

- Open nucleus

- Milk recording

- Progeny testing of male breeding animals

- Estimation of breeding value

- Selection of best single animals.

In principle, breeding programmes are similar for all types of dairy animals and based on pyramid organization aiming to realize the best results in certain production system (Petrović, 2000; Piacere et al., 2000; Sanna et al., 2002)

Programmes existing today include first of all the quantity of milked milk but also composition of milk, that is fat and protein content, and finally somatic cell count is included as factor important for improvement of the quality of final dairy products (Ugarte, 2003).

Fact that dairy sheep and goat breeding is mainly based on local breeds but also on imported populations imposes the need to discuss the issue of genetic diversity between domestic and foreign animals, also in relation to differences in management and production system. Therefore, genetic progress in milk yield in sheep and goat production is different.

In countries where ICAR methodology has been accepted more serious work on genetic improvement of milk production is present, part of published results are presented in tables 2 and 3 .

We can see from presented tables that through use of genetic knowledge and good breeding programmes it is possible, more or less, to realize planed annual genetic progress in milk traits. Variations in estimated annual increase of milk yield in sheep are from $0,8-6,1 \mathrm{~kg}$ and in goats $0,59-13,65 \mathrm{~kg}$. This means that milk yield of sheep and goats can be improved by $1-2 \%$ in relation to average milk yield of observed populations.

Table2. Genetic trend of milk production traits in several dairy sheep breeds per year (Barillet at al., 2004)

\begin{tabular}{|c|c|c|c|c|c|}
\hline Country & Period & Breed & $\begin{array}{c}\text { Milk yield } \\
\text { (liters/year) }\end{array}$ & $\begin{array}{c}\text { Fat content } \\
\mathrm{g} / 1 / \text { year }\end{array}$ & $\begin{array}{c}\text { Protein content } \\
\mathrm{g} / \mathrm{l} / \text { year }\end{array}$ \\
\hline France & $\begin{array}{l}1981-1992 \\
1984-1992 \\
1986-1994 \\
1981-1999 \\
1981-1999 \\
1981-1999 \\
1981-1999\end{array}$ & $\begin{array}{l}\text { Lacaune } \\
\text { Manech* } \\
\text { Lacaune } \\
\text { Lacaune } \\
\text { Manech* } \\
\text { Manech** } \\
\text { Basco-B. }\end{array}$ & $\begin{array}{l}5,6 \\
2,1 \\
6,1 \\
5,8 \\
4,3 \\
3,2 \\
3,5\end{array}$ & $\begin{array}{l}0,11 \\
0,21\end{array}$ & $\begin{array}{l}0,05 \\
0,14\end{array}$ \\
\hline Italy & $\begin{array}{l}1990-1994 \\
1990-1998\end{array}$ & $\begin{array}{l}\text { Sarda } \\
\text { Sarda }\end{array}$ & $\begin{array}{l}1,6 \\
2,2\end{array}$ & & \\
\hline Spain & $\begin{array}{c}1985-1993 \\
1985-1993 \\
1986-1992\end{array}$ & $\begin{array}{l}\text { Latxa* } \\
\text { Latxa** } \\
\text { Manchega }\end{array}$ & $\begin{array}{l}1,1 \\
0,8 \\
0,8\end{array}$ & & \\
\hline
\end{tabular}

* Redheaded

** Black headed 
Table3. Genetic trend of milk production traits in several goat breeds per year (Clement at al., 2002)

\begin{tabular}{|l|l|l|c|c|c|}
\hline \multicolumn{1}{|c|}{ Country } & \multicolumn{1}{|c|}{ Period } & \multicolumn{1}{c|}{ Breed } & $\begin{array}{c}\text { Milk yield } \\
\text { (liters/year) }\end{array}$ & $\begin{array}{c}\text { Fat yield } \\
\text { g/l/year }\end{array}$ & $\begin{array}{c}\text { Protein yield } \\
\text { g/l/year }\end{array}$ \\
\hline France & $1990-2000$ & Alpine & 13,65 & 0,55 & 0,50 \\
& $1990-2000$ & Saanen & 12,53 & 0,48 & 0,46 \\
\hline USA & $1995-2000$ & Alpine & 8,63 & 0,19 & 0,11 \\
& $1995-2000$ & Saanen & 6,99 & 0,32 & 0,23 \\
& $1995-2000$ & Toggenburg & 0,59 & 0,04 & 0,06 \\
\hline
\end{tabular}

Conclusion

Improvement of milk yield of sheep and goats demands analysis of genetic parameters and finding of selection compromise for simultaneous improvement of quantity and composition of milk.

For longer time experts engaged in selection work have been trying to determine genetic parameters for somatic cell count in milk.

Development of new methods in the field of genetics has made it possible to discuss the issue of improvement of milk yield in sheep and goats from other aspects. Knowledge on effect of major genes on protein content and especially genetic polymorphism of milk proteins where $\alpha$ s1-casein and $\beta$-lacto globulin were separated has been gathered.

Trends in breeding programmes of certain European countries indicate the possibility of improvement of milk yield in sheep and goat production per year by $1-2 \%$ compared to average milk yield of observed populations.

\title{
GENETSKI PRINCIPI UNAPREĐENJA MLEČNOSTI OVACA I KOZA
}

\author{
M. P. Petrović, C. Mekić, Dragana Ružić, M. Žujović
}

$$
\text { Rezime }
$$

U radu se analiziraju važniji genetski principi unapređenja mlečnosti ovaca i koza i predstavljaju trendovi u odgajivačkim programima nekih zemalja Evrope. Ukazuje se na značaj genetskih parametara mlečnosti ovaca i koza, ali i na intenzivan razvoj novih metoda genetike, čime se problem unapređenja mlečnosti rasvetljava i sa drugih aspekata. Radi utvrđivanja genetskih parametara za broj somatskih ćelija, definisan je i matematički pristup izračunavanja laktacijskog proseka broja somatskih ćelija u mleku ovaca i koza. Primenom saznanja iz oblasti genetike i dobrih odgajivačkih programa može sa više ili manje uspeha ostvarivati planirani godišnji genetski progres osobina mlečnosti. Varijacije za procenjeno godišnje genetsko povećanje mlečnosti kod ovaca iznose od 0,8-6,1 kg, a kod koza od 0,59-13,65 kg, što znači da se mlečnost ovaca i koza za godinu može unaprediti za $1-2 \%$.

\section{Literature}

1. ANALLA M, JIMENEZ G.I, MUNOZ S.A, SERRADILA J.M, FALAGAN A. (1996): Estimation of genetic parameters of milk yield and fat and protein contents of milk from murciano granadina goats. Journal of Dairy Science, 79, 1895-1898.

2. BARBIERI M.E., MANFREDI E., ELSEN J.M., RICORDEAU G., BOULLON J., GROSCLAUDE F., MAHE M.F.MBIBE B.(1995): Effects of the alpha-s1-casein locus on dairy performances and genetics parameters of Alpine goats. . Genet. Sel. Evol. 27,437-450.

3. BARILLET F., BOICHARD D.(1994): Use of first lactation test-day data for genetic evulation of the lacaune dayry sheep. Book of proceedings. 5 th World congres of genetic applied to livestock production, Canada. 18: 111-114

4. BARILLET F.(1997): Genetic of milk production. CAB International, 539-564 
5. BARILLET F.,ASTRUC J.M., CLEMENT V., LAGRIFFOUL G., MARIE C., PIACERE A.,RUPP R.,MANFREDI E.(2004): Improving milk yield and quality in dairy sheep and goats trough genetics. International symposium, Book of papers, 1-5, Spain, 28-30 october.

6. BERGONIER D., LAGRIFFOUL, G., CONCORDET D., BARILLET F., BERTHELOT X., (1995): Dynamique des infections mammaries subcliniques de la brebis laitiere en relation avec les comptages de cellules somatiques . Rencontre Rech. Rumin. 2, 299-302.

7. BOYAZOGLU J.G, FLAMANT J.C (1990): Meditteranean systems of animal production. The World of Pastoralism, 355-393.

8. BOYLAN W. J. (1989): The genetic basis of milk production in sheep. North American dairy sheep symposium. Minnesota, USA, 17, 1-8.

9. CARRIEDO J.A, BARO J.A, DE LA FUENTE L.F, SAN PRIMITIVO F (1995): Genetic parameters for milk yield in dairy sheep. J. Anim. Breed. Genetic112, 58-63.

10. CHIANESE L., GARRO G., MAURIELLO R.,LAEZZA P., FERRANTI P., ADDEO F.(1996): Occurrence of five alpha - s1 casein variants in ovine milk. Journal of Dairy Reseearch. 63, 49-59.

11. CLEMENT V., BOICHARD D., PIACERE A., BARBAT A., MANFREDI E.(2002): Genetic evaluation of Freanch goats for dairy and type traits. Proc. 7. World Congress, Applaed in Livestock Productione. Montpellier, 19-23 August 2002, INRA 01-46.

12. DELACROIX B.A., LAMBERT G.(2000): Sensoral properties and typicity of goat dairy prodacts. 7-th International conference of goats. Tours, France,May 2000. 559-563.

13. GROSCLAUDE F., MARTIN P.(1997): Casein polymorphisms Milk protein polymorphism. IDF Seminar, Brussels, Belgium, Proc. 241-253.

14. GONZALES R.M.C., GONZALO C., PRIMITIVO F., CARMENS P.(1995): Relationshep between somatic cell count and intramammary infection of the half udder in dairy ewes. J. Dairy Sci. 78, 27532759.

15. GUTIERREZ G.B., ARRANZ J., OTHMANE M.H., FUENTE L.F., PRIMITIVO S.(2001): Influence del genotipo de la $\beta$ lactoglobulina ovina sobre caracters cualitativos y rendimiento quesero individual en la raza Churra. ITEA, 22, 15-17.

16. MANFREDI E., RICORDEAU G., BARBIERI M.E., AMIGUES J., BIBE B.(1995): Genotipe caseine alpha s1 et selection des boucs sur descendance dans les races Alpine et Sanen. Genet. Sel. Evol27,451458.

17. MAHE M.F.,MANFREDI E., RICORDEAU G., PIACERE A., GROSCLAUDE G.(1993): Effets du polymorphisme de la caseine alpha s1 caprine sur les performances laitieres: analyse Intra descendance de boucs de race Alpine. Genet. Sel. Evol..,26,151-157.

18. MARIE C., BUCqUIER F., BANILLET F. (1996): Influence du potential laitiez sur les composantes de l'efficacite alimentaire de brebis lacaune. In: Institute de l'Elevage (ed) 3eimes Rencontres Resherches Ruminants, Paris, 4-5 Decembre 1996, Paris, vol. 3, 297-300.

19. PETROVIĆ P.M. (2000): Genetika i oplemenivanje ovaca. Naučna Knjiga, Beograd, 365 pp.

20. PETROVIĆ P.M., SKALICKI Z., ŽUJOVIĆ M., MEKIĆ C., STOJKOVIĆ M., DRAGANA RUŽIĆ (2000): Ispitivanje genetičkih parametara osobina mlečnosti ovaca. Arh.poljopr.nauke 61, 213, 93-97.

21. PETROVIĆ P.M.,MEKIĆ C..NEGOVANOVIĆ D., DRAGANA RUŽIĆ., ŽUJOVIĆ M. STOJKOVIĆ M. (2000): Potential of sheep milk production on Stara planina. Symposium Milk production and processing, Beograd. Zbornik radova 59-63

22. PETROVIĆ P.M, .ŽUJOVIĆ M., NEGOVANOVIĆ D., RUŽIĆ D. STELA STRSOGLAVEC (2002): Multi purpose sheep production in Serbia- 53 rd Annual Meeting, Cairo ,22

23. PETROVIĆ P.M., ŽUJOVIĆ M., NEGOVANOVIĆ D., DRAGANA RUŽIĆ, STELA STRSOGLAVEC (2002):Uticaj paragenetskih faktora na mlečnost. Biotehnologija u stočarstvu, vol 18, 1-2, 23-27

24. PETROVIĆ P.M., SKALICKI Z., DRAGANA RUŽIĆ., ŽUJOVIĆ M. (2003): Investigation of genetic and paragenetic parameters of milk yield of sheep on Stara Planina mountain. Biotechnology in Animal Husbandry 19,5-6,113-117.

25. PETROVIĆ P.M., PETROVIĆ M.M, DRAGANA RUŽIĆ-MUSLIĆ, ŽUJOVIĆ M (2004): Present situation in sheep and goat milk production in .International symposium -The future of the sheep and goat dairy sectors. Zaragoza, Spain, 28-30 october 
26. PETROVIĆ P.M, .ŽUJOVIĆ M., NEGOVANOVIĆ D., RUŽIĆ D. (2001): Značaj novih metoda selekcije u savremenom sistemu gajenja ovaca. VI International Symposium "Systems of Animal Breeding of the new millennium". Biotechnology in Animal Husbandry, 17 (5-6) 159-167.

27. PETROVIĆ P.M., DRAGANA RUŽIĆ-MUSLIĆ, ŽUJOVIĆ M., SKALICKI Z., PERIŠIĆ P (2004): Analysis of the livestock production system present on Stara planina mountain from the aspect of production of hard cheese-kackaval.. Biotechnology in Animal husbandry, vol 20, 1-2,81-89

28. PETROVIĆ P.M., MEKIĆ C.., RUŽIĆ D., ŽUJOVIĆ M. (2005):Investigation of heritability and genetic correlations of milk traits in sheep . Biotechnology in Animal Husbandry, 20.3-4.

29. PIACERE A., BOUE P., ROGUET J.M.(2000): Objectives and organization of the Franch selection programe . 7-th International conference of goats.Tours, France,May 2000. p.1049.

30. PIRISI A., PIREDDA G., PAPOFF C.M., DISALVO R., PINTUS S., GARRO G., FERNANTI P., CHIANESE L.(1999): Effect of sheep alpha s1 casein CC, CD and DD genotipes on milk composition and cheesmaking properties. Journal of Dairy Research. 66, 409-419.

31. RECIO I., FERNANDEZ.A., MARTIN P.J., RAMOS M.(1997): $\beta$ lactoglobulin polymorphism in ovine breeds influence on cheesmaking properties and milk composition. Lait, 77, 259-265.

32. RUPP R., CLEMENT V., PIACERE A., MANFREDI E.(2004): Goat milk somatic cell count is a heritable traits. 55-th Annual meeting of EAAP, 5-8. September, Slovenia, Book of Abstracts, N. GM2.

33. SANNA S. R., CARTA A., CASU S.(1997): Covarians components estimates for milk composition traits in Sarda dairy sheep using a bivariate animal model. Small Ruminants Research.25,79-84.

34. SANNA S. R., CASU S. CARTA A .(2002):Breeding programs in dairy sheep. Proc. 7. World Congress, Applied in Livestock Production. Montpellier, 19-23 August 2002, INRA 01-34.

35. SERRANO M. D., PEREZ G., MONTORO V., JURADO J. (1997): Changes in estimates of variance components and genetic progress due to the inclusion of genetic groups for several milk traits in manchega sheep breed. EAAP. 48th Annual Meeting, Viena, 69 p.

36. SERRANO M., UGARTE E, JURADO J.J, PEREZ M.D, LEGARRA A.(2001): Test day model and genetic parameters in Latxa and Manchega dairy ewes. Livestock Production Science, 67,253-264

37. SERRADILLA J.M.(2002): New techniques for sustainable sheep and goat production. Course material. Tunis, 12. 9-20.

38. UGARTE E.(1996): Genetic parameters and trends for milk production of Blond-faced latxa sheep using bayesan analysis. Journal of Dairy Science,79:2268-2277.

39. UGARTE E.(2003):Current state of breeding dairy sheep programs. Biotechnology in Animal Husbandry $19,5-6,107-112$

40. ŽUJOVIĆ M., PETROVĆ P.M., JOSIPOVIĆ S., ZORICA TOMIĆ, CMILJANIĆ R., DUŠICA TOMAŠEVIĆ, STELA STRSOGLAVEC MEMIŠI N. (2002): Uticaj ranog odlučivanja jaradi blizanaca na njihov razvoj i proizvodnju mleka i mesa. Biotehnologija u stočarstvu, 15. Inovacije u stočarstvu, 1415.novembar 2002, 80-85. 